\title{
Reclassification of Shewanella putrefaciens Owen's genomic group II as Shewanella baltica sp. nov.
}

\author{
Frank Ziemke, ${ }^{\uparrow} \uparrow$ Manfred G. Höfle, ${ }^{1}$ Jorge Lalucat ${ }^{2}$ \\ and Ramon Rosselló-Morał \\ Author for correspondence: Frank Ziemke. Tel: +498856 603876. Fax: +498856 602003. \\ e-mail: frank_ziemke@bmg.boehringer-mannheim.com
}

\footnotetext{
1 GBF - Gesellschaft für Biotechnologische Forschung, AG Mikrobielle Ökologie, Mascheroder Weg 1, D-38124

Braunschweig, Germany

2 Institut Mediterrani d'Estudis Avancats and Departament de Biologia Ambiental, Universitat de les Illes Balears (CSIC-UIB), Crtra. Valldemossa Km 7.5, 07071 Palma de Mallorca, Spain
}

\begin{abstract}
The taxonomic relationship between several Shewanella putrefaciens isolates from the Baltic Sea and reference strains of this species is presented in this study. Results from DNA-DNA hybridization using a newly developed nonradioactive detection system and from 165 rRNA gene sequencing demonstrated that $S$. putrefaciens is a heterogeneous species containing more than a single genomic group. The genomic group II was phylogenetically, genotypically and phenotypically distant enough from the species type strain to be classified as a single species within the genus Shewanella. Therefore, we propose to reclassify Owen's genomic group II as Shewanella baltica sp. nov. with the type strain NCTC 10735.
\end{abstract}

Keywords: Shewanella putrefaciens, Shewanella baltica, DNA-DNA hybridization, 16S rRNA gene sequencing

\section{INTRODUCTION}

The genus Shewanella comprises several Gram-negative species which are widely distributed in marine and freshwater environments. The genus seems to play an important role in the turnover of organic matter coupled to anaerobic respiration electron acceptors, such as $\mathrm{Fe}^{3+}, \mathrm{Mn}^{4+}$ and $\mathrm{NO}_{3}^{-}(2,4,8,26,29,33)$. Shewanella putrefaciens has been frequently isolated from marine water samples and spoiling fish $(17,34$, 37). Shewanella alga (formerly classified as $S$. putrefaciens) was isolated from human faeces, skin ulcers and other clinical samples $(6,14,19,27,28)$.

The genus Shewanella is affiliated with the $\gamma$-subclass of the Proteobacteria within the family Vibrionaceae $(23,30,41)$. Strains are motile rods and facultatively anaerobic but with a strictly respiratory metabolism. The type species, $S$. putrefaciens (23), was originally

\footnotetext{
†Present address: Boehringer Mannheim GmbH, Mikro- und Zellbiologische Analytik IPK, TE-A3, Nonnenwald 2, D-82377 Penzberg, Germany. $\ddagger$ Present address: Max-Planck-Institut für Marine Mikrobiologie, Celsiusstrasse 1, D-28359 Bremen, Germany.

Abbreviations: ARDRA, amplified rDNA restriction analysis; RAPD, randomly amplified polymorphic DNA; HA, hydroxyapatite; DIG, digoxigenin. The EMBL accession numbers for the sequences reported in this paper are AJ000213-AJ000216 and AJ001277-AJ001288.
}

classified as Achromobacter putrefaciens (7) and has been the subject of continuous nomenclature changes as well as reclassifications $(21,23,27,35,41)$. Based on DNA-DNA hybridization experiments, Owen et al. (28) showed that the species comprised at least four clearly separated genomic groups (I-IV). One of the $S$. putrefaciens genomic groups (IV) has been reclassified as a new species, i.e. $S$. alga $(27,36)$. This species includes the most halotolerant members of the genus such as the $\mathrm{Fe}^{3+}$-reducing organisms (30), as well as most of the clinical isolates of the genus $(12,27)$. However, in spite of the intraspecific diversity of $S$. putrefaciens, the three remaining genomic groups are still classified into the same species $(12,30)$.

During a genotypic screening study of heterotrophic bacteria from the Baltic Sea, a large set of isolates was obtained from different sampling sites and years (2). Using low-molecular-weight RNA profiling and amplified rDNA restriction analysis [ARDRA (40)], 113 isolates could be identified as $S$. putrefaciens Owen's group II $(13,43,44)$. The genetic structure of this $S$. putrefaciens population was further studied using randomly amplified polymorphic DNA (RAPD) analysis; 13 sub-groups (RAPD genotypes) were found (43). Several strains representing the most prominent RAPD genotypes were chosen for the present taxonomic study. 
For this purpose, 16S rRNA gene sequences, DNADNA similarity and phenotypic traits of selected strains were determined. For DNA-DNA hybridization experiments, we developed a new micro-scale method combining the well-established hydroxyapatite (HA) method $(1,22)$ with non-radioactive detection of the released DNA. The major advantages of the method are the small amount of DNA required and utilization of a digoxigenin (DIG) labelling/ antibody detection system rather than radioactive labelling.

In summary, our results showed that genomic group II of $S$. putrefaciens is phylogenetically, genotypically and phenotypically distant enough from the rest of the $S$. putrefaciens members to be classified as a new species, for which we propose the name Shewanella baltica sp. nov.

\section{METHODS}

Bacterial strains and cultivation. Reference strains used in this study were obtained from the Culture Collection of the Laboratorium voor Microbiologie Universiteit Gent (LMG), the Deutsche Sammlung von Mikroorganismen und Zellkulturen (DSMZ) and the National Collection of Type Culture (NCTC). One-hundred-and-thirteen strains of $S$. putrefaciens were isolated from Baltic Sea water samples as described previously $(13,43)$. All strains were aerobically cultured in half-strength marine broth 2216 (MB-0.5; Difco) overnight at $30^{\circ} \mathrm{C}$ with agitation.

Physiological and biochemical tests. Temperature requirements were determined for ten reference strains (listed in Table 2) by growing the strains on MB- 0.5 agar medium at different temperatures. Inoculated agar plates were incubated for $14 \mathrm{~d}$ at $4{ }^{\circ} \mathrm{C}$ and $7 \mathrm{~d}$ at $37^{\circ} \mathrm{C}$. Growth was considered positive if the strains were able to form visible colonies on the solid medium. FeS production on triple sugar iron (TSI) agar medium (Difco) was determined after incubation at $25^{\circ} \mathrm{C}$ for $2 \mathrm{~d}$. For the enzyme tests, API 20NE (bioMérieux) and the BIOLOG system, strains were grown on MB- 0.5 agar medium at $25^{\circ} \mathrm{C}$ for $2 \mathrm{~d}$. Bacterial biomass was scraped from the agar plates and resuspended in $0.85 \%$ $\mathrm{NaCl}$. The suspension was adjusted to $\mathrm{OD}_{595} 0.8$ for the enzyme tests, 0.35 for the BIOLOG system and 0.2 for API $20 \mathrm{NE}$. Tests for the production of constitutive enzymes were performed for the ten reference strains at $37^{\circ} \mathrm{C}$ for $4 \mathrm{~h}$ with API ZYM stripes (bioMérieux) as recommended by the manufacturer. The metabolic profiles of 34 strains of genomic group II, and two reference strains from each of groups I and III and S. alga were determined with BIOLOGGN plates, which were incubated at $25^{\circ} \mathrm{C}$ for $7 \mathrm{~d}$ based on the recommendations of Rüger \& Krambeck (32). Microtitre plates were checked for positive reactions both visually and by measuring the oxidation of substrates via the production of purple formazan from a tetrazolium redox dye with an Emax precision microplate reader (Molecular Devices) at $595 \mathrm{~nm}$. Tests for utilization of different substrates and for additional enzymes were performed for ten reference strains with API 20NE stripes following the protocol of the manufacturer.

DNA isolation and $\mathbf{G}+\mathbf{C}$ content determination. DNA was isolated following the method of Marmur (25). The $G+C$ content was determined by hydrolysing the DNA enzymically and quantifying the nucleosides by HPLC as previously reported (5).

DNA labelling. Reference DNA was double-labelled using DIG-11-dUTP and biotin-16-dUTP (Boehringer Mannheim). Labelling was performed using the Boehringer Mannheim nick-translation kit. The optimal ratio of the nucleotide mixture was 0.75 vol. DIG-11-dUTP:0.25 vol. biotin-16-dUTP. DNA $(1 \mu \mathrm{g})$ was labelled during $90 \mathrm{~min}$ incubation according to the protocol of the manufacturer. Labelled DNA was precipitated with ethanol and resuspended in $200 \mu \mathrm{l}$ distilled water. One microlitre of this suspension was used to measure the efficiency of the reaction following the protocol mentioned below.

DNA-DNA hybridization. Experiments were performed using a modification of the Lind \& Ursing method (22). Between 15 and $50 \mathrm{ng}$ labelled DNA was mixed with $15 \mu \mathrm{g}$ unlabelled DNA in $0.1 \mathrm{ml} 0.28 \mathrm{M}$ phosphate buffer (PB), pH 6.8. This mixture was denatured by heating at $100^{\circ} \mathrm{C}$ for $10 \mathrm{~min}$ and subsequent cooling in an ice/water bath. After denaturation, the mixture was incubated for $16 \mathrm{~h}$ at $64^{\circ} \mathrm{C}\left(30^{\circ} \mathrm{C}\right.$ below the melting temperature of the homologous DNA, which was considered to be the optimal temperature). The solution was covered with $50 \mu \mathrm{l}$ light mineral oil (Sigma) to avoid evaporation during incubation. Single- and double-stranded DNA was eluted on HA following the batch procedure of Brenner et al. (1). Elutions were performed in duplicate. The mixture was diluted with distilled water to a final volume of $0.2 \mathrm{ml} ; 50 \mu \mathrm{l}$ of the diluted mixture was added to $0.2 \mathrm{ml}$ rehydrated HA (DNA grade Bio-Gel HTP; Bio-Rad), which corresponded to about $20 \mathrm{mg}$ dry weight, and equilibrated with $0.14 \mathrm{M}$ PB. The preparation was mixed thoroughly and incubated for $15 \mathrm{~min}$ at $59^{\circ} \mathrm{C}\left(5^{\circ} \mathrm{C}\right.$ below the temperature used for reassociation); the single- and the double-stranded DNA was then eluted using four washes of $0.25 \mathrm{ml} 0.14 \mathrm{M}$ $\mathrm{PB}, 0.2 \%$ SDS and two washes of $0.2 \mathrm{ml} 0.4 \mathrm{M} \mathrm{PB}$, respectively.

Detection of eluted DNA. From each batch of eluates $(0 \cdot 14 \mathrm{M}$ and $0.4 \mathrm{M} \mathrm{PB}$ ), $200 \mu \mathrm{l}$ was incubated for $2 \mathrm{~h}$ in streptavidincoated microtitre plates (Boehringer Mannheim) with $0 \cdot 1 \%$ BSA (Sigma). DNA eluted with $0 \cdot 4 \mathrm{M}$ PB was denatured and chilled on ice prior to incubation on the microtitre plates. Wells were washed with PBS $[0.3 \mathrm{M} \mathrm{NaCl}, 5 \mathrm{mM}$ $\mathrm{Na}_{2} \mathrm{HPO}_{4}, 1.5 \mathrm{mM} \mathrm{KH} \mathrm{PO}_{4}(\mathrm{pH} \mathrm{7.2)].} \mathrm{Washes} \mathrm{were} \mathrm{fol-}$ lowed by $1 \mathrm{~h}$ incubation with anti-DIG antibodies conjugated with alkaline phosphatase (Boehringer Mannheim) in $200 \mu \mathrm{l} \mathrm{PBS}$ and $0.1 \%$ BSA. In both cases, incubations were carried out at room temperature and with agitation. After antibody incubation, wells were washed with PBS. Detection was performed with $250 \mu \mathrm{l} p$-nitrophenyl phosphate [1 $\mathrm{mg}$ $\mathrm{ml}^{-1}$ in $7.5 \mathrm{mM} \mathrm{Na}_{2} \mathrm{CO}_{3}, 15.5 \mathrm{mM} \mathrm{NaHCO}, 1 \mathrm{mM} \mathrm{MgCl}_{2}$ (pH 9.6)] at $37^{\circ} \mathrm{C}$ without agitation; colour development was measured at $405 \mathrm{~nm}$ (39).

Treatment of hybridization data. Homologous and heterologous reassociations were processed simultaneously. The degree of reassociation (binding ratio) was expressed as the percentage of labelled DNA released with $0.4 \mathrm{M}$ PB compared to the total released labelled DNA. The relative binding ratio of heterologous DNA was expressed as the percentage of homologous binding. Pooled standard deviations (SD) of all experiments ranged from 1 to $4 \%$.

Determination of 165 rRNA gene sequences. Bacterial biomass was lysed in alkaline lysis buffer containing $0.05 \mathrm{M}$ $\mathrm{NaOH}$ and $0.25 \%$ SDS. Cellular debris was pelleted and the supernatant was diluted tenfold. Diluted supernatant $(4 \cdot 0 \mu \mathrm{l})$ 


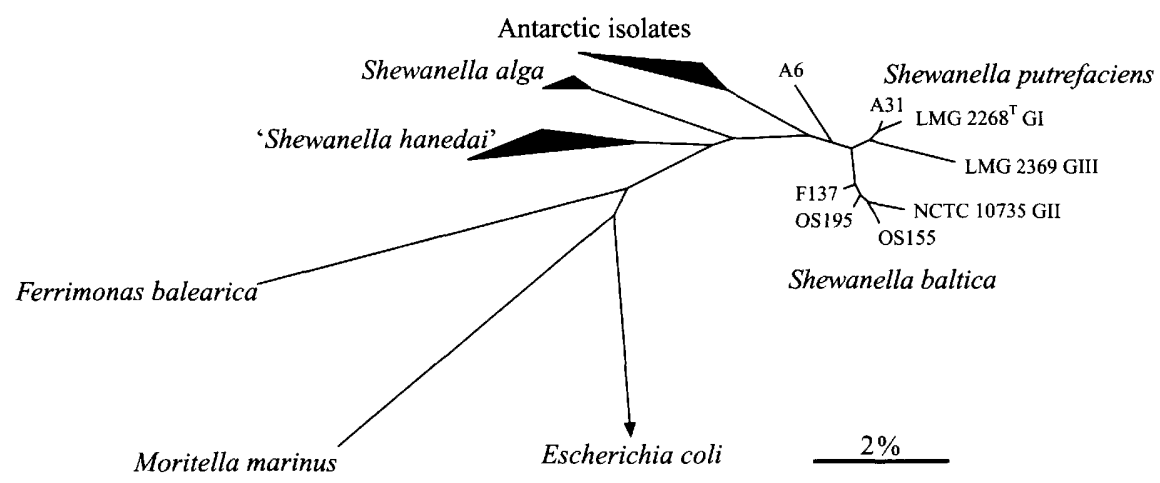

Fig. 1. $16 \mathrm{~S}$ rRNA-based tree reflecting the phylogenetic relationship of the strains belonging to $S$. baltica NCTC 10735 (AJ000214), OS155 (AJ000215), OS195 (AJ000216), F137 (U91552), and the closest relatives available in the EMBL database: S. putrefaciens LMG 2268 ${ }^{\top}$ (X81623), LMG 2369 (AJ000213) and A31 (U91550), A6 (U91549); the Antarctic isolates SC2A (U91591), Shewanella sp. ACAM 122 (U39398), 'Shewanella frigidimarina' A173 (U85902); S. alga IAM 14159 (U91546), FeRed (X81622), BrY (X81621); the Shewanella hanedai complex comprising S. hanedai (X82132), Shewanella benthica (X82131) and 'Shewanella gelidimarina' ACAM 456 (U85907); Moritella marinus (formerly Vibrio marinus, X82142) and Ferrimonas balearica (X93021). E. coli (X80725) was used as the outgroup for the calculation. GI, GII and GIII indicate the reference strains of each of Owen's genomic groups (28). The tree is based on the results of a distance matrix analysis of complete or almost complete $16 \mathrm{~S}$ rRNA sequences. Similar affiliation of $S$. baltica was observed when the tree was calculated using the maximum-likelihood approach. The mistaken sequence of $\mathrm{BrY}$ found in the database (12) has been currently corrected.

was used for the amplification of the $16 \mathrm{~S}$ rRNA genes via PCR with the forward primer 16F27 (5'-AGAGTTTGATCMTGGCTCAG-3') and the reverse primer 16R1525 (5'AAGGAGGTGWTCCAGCC-3'). PCR reactions were carried out under conditions described previously $(10,15,18)$. Amplification products were purified with Microcon-100 concentrators (Amicon). Purified 16S rDNA was sequenced directly using an Applied Biosystems 373A DNA Sequencer and the manufacturer's protocols for Taq cycle-sequencing with fluorescent dye-labelled dideoxynucleotides (PerkinElmer). The primers used for sequencing have been previously described $(10,15,20)$. Partial sequences were generated using the primer 16R518 (5'-CGTATTACCGCGGCTGCTGG-3').

Analysis of sequence data. New sequences were added to an alignment of about 5300 homologous bacterial 16S rRNA primary structures using the aligning tool of the ARB program package (38). Similarity and distance matrices were calculated with the ARB-PHYL program of the same package. Phylogenetic trees were constructed using subsets of data that included representative sequences of Ferrimonas, Moritella and Shewanella species (24). We used distance matrix and maximum-likelihood methods as implemented in the programs PHYLIP (11), ARB and fastDNAml (24). For partial sequences, similarities were calculated for positions 28-490 [Escherichia coli 16S rRNA gene sequence numbering (3)].

Nucleotide sequence accession numbers. The EMBL database accession numbers of the nucleotide sequences are as follows (partial sequences are indicated by asterisks): strain LMG 2369, AJ000213; NCTC 10735, AJ000214; OS155, AJ000215; OS195, AJ000216; OS106*, AJ001281 ; OS182*, AJ001277; OS183*, AJ001284; OS189*, AJ001287; OS197*, AJ001285; OS208*, AJ001283; OS257*, AJ001279; OS268*, AJ001286; OS278*, AJ001280; OS284*, AJ001288; OS295*, AJ001282; and OS669*, AJ001278.

\section{RESULTS}

\section{Phylogenetic affiliation}

Nearly complete 16S rRNA gene sequences were obtained for the strains LMG 2369, NCTC 10735, OS155 and OS195. Comparative analysis of the gene sequences confirmed the affiliation of all strains with the same phylogenetic branch of $S$. putrefaciens type strain LMG $2268^{\mathrm{T}}$ (Fig. 1). The reference strain of genomic group III (LMG 2369) was the closest relative to the type strain of the species, with $98.6 \%$ sequence similarity. All three strains of group II (NCTC 10735, OS155 and OS195) affiliated with more than $99 \%$ of sequence similarity (Table 1). The reference strain of this group, NCTC 10735, had sequence similarities of 97.8 and $97.4 \%$ with the reference strains of the genomic groups I and III, respectively.

Additionally, partial 16S rRNA gene sequences $(E$. coli positions 28-490) of 22 selected Baltic Sea isolates were obtained. Results showed a high degree of sequence conservation between the Baltic isolates and the group II reference strain, NCTC 10735. Internal similarity was $98 \cdot 3-100 \%$, whereas similarity values with the reference strains of groups I and III were always below $96.1 \%$ in this variable fragment (Table $1)$.

\section{G $+\mathbf{C}$ content and DNA-DNA hybridization}

$\mathrm{G}+\mathrm{C}$ content and DNA-DNA similarities were determined for five Baltic isolates and reference strains of each genomic group and $S$. alga. The Baltic isolates and strain NCTC 10735 shared similar G + C contents, $45 \cdot 7-46.8 \mathrm{~mol} \%$ (Table 1 ). DNA-DNA hybridization experiments were performed with our method using a 
Table 1. DNA base composition, DNA-DNA relatedness and 165 rDNA similarity results of $S$. putrefaciens strains representing all genomic groups of Owen et al. (28) and S. alga

\begin{tabular}{|c|c|c|c|c|c|c|c|c|}
\hline \multirow[t]{3}{*}{ Genomic group } & \multirow[t]{3}{*}{ Strain } & \multirow{3}{*}{$\begin{array}{c}\mathbf{G}+\mathbf{C} \text { content } \\
(\mathrm{mol} \%)^{*}\end{array}$} & \multicolumn{4}{|c|}{ Similarity (\%) } & \multirow{2}{*}{\multicolumn{2}{|c|}{$\begin{array}{c}\text { 16S rDNA sequence } \\
\text { similarity } \\
\text { with NCTC } 10735(\%)\end{array}$}} \\
\hline & & & \multirow[t]{2}{*}{ NCTC 10735} & \multirow[t]{2}{*}{ OS155 } & \multirow[t]{2}{*}{ OS189 } & \multirow[t]{2}{*}{ OS278 } & & \\
\hline & & & & & & & Complete & Partial $\dagger$ \\
\hline \multirow[t]{6}{*}{ II } & NCTC 10735 & $46 \cdot 1$ & 100 & 88 & 62 & 74 & 100 & 100 \\
\hline & OS155 & $46 \cdot 7$ & 70 & 100 & 68 & 70 & $99 \cdot 3$ & $98 \cdot 5$ \\
\hline & OS182 & $46 \cdot 6$ & 84 & 94 & 75 & 69 & ND & $99 \cdot 1$ \\
\hline & OS195 & $46 \cdot 8$ & 70 & 69 & 72 & 69 & $99 \cdot 2$ & $99 \cdot 4$ \\
\hline & OS189 & $45 \cdot 7$ & 62 & 79 & 100 & 70 & ND & $99 \cdot 8$ \\
\hline & OS278 & $45 \cdot 7$ & 76 & 77 & 61 & 100 & ND & $99 \cdot 6$ \\
\hline I & LMG $2268^{\mathrm{T}}$ & $(43 \cdot 9)$ & $11(26-47)$ & ND & 28 & 16 & 97.8 & $96 \cdot 1$ \\
\hline III & LMG 2369 & $(46 \cdot 9)$ & $5(14-38)$ & ND & 17 & 7 & $97 \cdot 4$ & $94 \cdot 0$ \\
\hline \multirow[t]{2}{*}{ S. alga (IV) } & LMG 2265 & $(52 \cdot 6)$ & $1(9-27)$ & ND & 4 & 16 & ND & $88 \cdot 8$ \\
\hline & Pooled SD & 0.41 & 1 & 3 & 2 & 4 & & \\
\hline
\end{tabular}

ND, Not determined.

*Values in parentheses were determined by Owen et al. (28).

$\dagger$ Partial sequences (28-490; E. coli $16 \mathrm{~S}$ rRNA gene sequence numbering) were obtained from 22 Baltic strains isolated from different locations in different years.

Table 2. Differential characteristics of the different genomic groups of S. putrefaciens and S. alga

\begin{tabular}{|c|c|c|c|c|c|c|c|c|c|c|}
\hline \multirow[t]{2}{*}{ Characteristics* } & \multicolumn{2}{|c|}{ Group I } & \multicolumn{4}{|c|}{ Group II } & \multicolumn{2}{|c|}{ Group III } & \multicolumn{2}{|c|}{ S. alga } \\
\hline & LMG $2268^{T}$ & DSM 1818 & NCTC 10735 & NCTC 10736 & OS155 & OS195 & LMG 2266 & LMG 2369 & BrY & LMG 2265 \\
\hline \multicolumn{11}{|l|}{ Growth at: } \\
\hline $4{ }^{\circ} \mathrm{C}$ & + & + & + & + & + & + & - & - & - & - \\
\hline $37^{\circ} \mathrm{C}$ & + & + & $-\dagger$ & - & - & - & + & + & + & + \\
\hline FeS production on TSI agar & + & + & + & + & - & + & + & + & + & + \\
\hline \multicolumn{11}{|l|}{ Production of: } \\
\hline Chymotrypsin ${ }^{a}$ & + & + & $(+) \ddagger$ & $(+) \ddagger$ & - & - & + & + & + & + \\
\hline $\begin{array}{l}N \text {-Acetyl- } \beta \text { - } \\
\text { glucosaminidase }^{a}\end{array}$ & - & - & + & + & - & + & - & - & $(+)_{\ddagger}^{\ddagger}$ & $(+) \ddagger$ \\
\hline Arginine dihydrolase ${ }^{b}$ & - & - & - & + & - & - & - & - & - & - \\
\hline Urease $^{b}$ & - & - & - & + & - & - & - & - & + & - \\
\hline \multicolumn{11}{|l|}{ Utilization of: } \\
\hline$\alpha$-Cyclodextrin ${ }^{c}$ & - & - & + & + & + & + & + & + & - & - \\
\hline Dextrin $^{c}$ & - & - & + & + & - & + & + & + & - & - \\
\hline Glycogen $^{e}$ & - & - & + & + & - & + & - & - & - & - \\
\hline Tween $80^{c}$ & + & + & + & + & - & + & - & - & + & + \\
\hline D-Glucose $e^{d}$ & - & - & + & + & + & + & + & + & - & - \\
\hline L-Arabinose ${ }^{d}$ & - & + & - & - & - & - & + & + & - & - \\
\hline Maltose $^{d}$ & - & - & + & + & + & + & + & + & - & - \\
\hline Gentiobiose $^{c}$ & _- & - & + & + & + & + & - & - & - & - \\
\hline Cellobiose $^{c}$ & - & - & + & + & + & + & - & - & - & - \\
\hline Sucrose $e^{c}$ & - & - & + & + & + & + & - & + & - & - \\
\hline$N$-Acetylgalactosamine ${ }^{c}$ & - & - & - & - & - & - & + & - & + & + \\
\hline$N$-Acetylglucosamine ${ }^{d}$ & + & - & + & + & + & + & + & + & + & + \\
\hline D-Gluconate ${ }^{d}$ & - & - & + & + & + & + & - & - & - & - \\
\hline$\alpha$-Hydroxybutyrate ${ }^{c}$ & - & - & - & - & - & - & - & - & + & + \\
\hline Caprate $^{b}$ & - & - & - & - & - & + & + & - & + & + \\
\hline Adipate $^{b}$ & - & - & - & + & - & - & - & - & - & - \\
\hline Malate $^{b}$ & + & - & + & + & - & + & + & - & + & + \\
\hline Citrate $^{d}$ & - & $\mathrm{d} \S$ & + & + & + & + & - & - & - & - \\
\hline
\end{tabular}

$* a$, Results from API ZYM; $b$, results from API 20NE; $c$, results from BIOLOG; $d$, results from API 20NE and BIOLOG.

$\dagger$ Weak growth in one duplicate.

\$ Weak reaction.

$\S$ d, Different reaction, i.e. positive with API 20NE and negative with BIOLOG. 
non-radioactive detection system. The pooled SD of the different experiments was $1-4 \%$, indicating good correspondence between duplicates. All Baltic isolates studied and the reference strain of group II formed a homogeneous cluster with an internal genomic similarity of $61-100 \%$. This genomic group was distant from groups I and III, showing a maximal similarity value of $28 \%$ between the three genomic groups. In summary, the results from DNA-DNA hybridization as well as from phylogenetic analysis indicate that $S$. putrefaciens consists of three distant genomic groups.

\section{Phenotypic characteristics}

Strains of the different genomic groups of $S$. putrefaciens and two strains of $S$. alga were evaluated for different phenotypic traits. All strains of genomic groups I and II were able to grow at $4{ }^{\circ} \mathrm{C}$ on solid MB0.5 medium, whereas strains of $S$. alga and group III did not grow at this temperature (Table 2). In contrast to all other strains tested, strains of genomic group II were not able to grow at $37^{\circ} \mathrm{C}$. All strains, except OS155, were able to produce FeS precipitates via reduction of thiosulfate on TSI agar medium.

The API ZYM test was used to determine enzymes that were constitutively expressed during growth. Only two out of the 19 enzymes tested were different between the genomic groups and $S$. alga (Table 2). All strains of genomic groups I and III and $S$. alga produced chymotrypsin, which is contrary to the situation in genomic group II, although strains NCTC 10735 and NCTC 10736 exhibited a weak reaction. In contrast to all other strains tested, strains of genomic group II were able to produce $N$-acetyl- $\beta$-glucosaminidase constitutively.

The BIOLOG system was used to assess the metabolic profile of $S$. putrefaciens group II. Thirty-four strains of group II, two strains each of groups I and III and $S$. alga were included in this study. Although the strains of group II varied in their utilization of some compounds, e.g. dextrin, glycogen and Tween 80 (Table 2), several marker substrates, such as gentiobiose, cellobiose and D-gluconate, were identified that were suitable for differentiation of this genomic group from groups I and III and from $S$. alga.

Selected results from API 20NE are also listed in Table 2. Results were in agreement with data from the BIOLOG system but gave no additional information for differentiating the genomic groups.

\section{DISCUSSION}

S. putrefaciens is a heterogeneous species comprising more than one genomic group. Although the species has been frequently taxonomically characterized and reclassified, the three genomic groups are still considered to belong to $S$. putrefaciens $(27,28,30)$.

Recently, 113 isolates from the Baltic Sea have been identified as $S$. putrefaciens $(13,43)$. All isolates belonged to DNA-DNA similarity group II, as demonstrated by ARDRA (44). Examination of the genetic structure of this $S$. putrefaciens population using RAPD analysis showed that it comprised several sub-groups (RAPD genotypes). The different RAPD genotypes corresponded to a certain extent to characteristic physiological traits as well as to different ecological niches (43). For the taxonomic characterization presented in this study, representative Baltic isolates of $S$. putrefaciens were compared with reference strains.

We determined the 16S rRNA gene sequence of the reference strains for each of Owen's genomic groups and two representative strains of the most frequent RAPD genotypes. The gene sequence comparison demonstrated the affiliation of all sequenced strains within the same phylogenetic branch (Fig. 1). In accordance with the genomic subdivision of the species (28), the reference strains of Owen's groups represented single sub-branches within the $S$. putrefaciens phylogenetic complex. The two representative strains from the Baltic Sea affiliated with NCTC 10735 in accordance with the preliminary identification (44). A comparison of the partial sequences of 22 selected strains indicated phylogenetic homogeneity within genomic group II. This group of strains represented all RAPD genotypes isolated from different sampling years and sampling sites of the central Baltic Sea (43, 44). Thus, the selected strains covered the widest range of diversity among the Baltic Sea isolates. The 28-490 fragment ( $E$. coli positions) was chosen because maximal sequence differences were observed in this fragment when reference strains were compared.

DNA-DNA hybridization experiments were performed with the newly developed non-radioactive method. Results were in good agreement with previous data obtained by traditional methods $(27,28,30,31)$. Genomic similarities among the reference strains of the three genomic groups and $S$. alga were comparable to those previously reported (Table $1 ; 27,28,30$ ). Our data confirmed the classification of three genomic groups within $S$. putrefaciens. A high degree of DNA-DNA similarity was observed between the Baltic isolates and the reference strain NCTC 10735. Although internal similarity values were $61-94 \%$, this group could be clearly distinguished from the other genomic groups. Results of phenotypic analyses were in good accordance with genotypic data. Based on these results, we developed a phenotypic profile for the identification of the species within the genus Shewanella which can be used to distinguish group II from its closest relatives (Table 3 ). In contrast to the observations of Domínguez et al. (9), who used the API system, we found that the different members of the genus Shewanella could be identified using the BIOLOG system with the modified protocol as recommended by Rüger \& Krambeck (32). Reference strains of the different genomic groups were added to the database provided by the manufacturer to enable clear differentiation of the groups. 
Table 3. Differentiation of S. baltica from S. putrefaciens and S. alga

Designation of strains examined: $S$. putrefaciens group I, LMG 2268 ${ }^{\mathrm{T}}$ and DSM 1818; $S$. putrefaciens group III, LMG 2266 and LMG 2369; S. alga, BrY and LMG 2265. For the number of $S$. baltica strains examined see Methods.

\begin{tabular}{|lccc|}
\hline Characteristics & S. putrefaciens & S. baltica & S. alga \\
\hline Number of strains examined & 4 & $4 / 34$ & 2 \\
Growth at: & + & $+(4)$ & - \\
$4^{\circ} \mathrm{C}$ & + & $-(4)$ & + \\
$37^{\circ} \mathrm{C}$ & + & $(-) \dagger$ & + \\
Production of chymotrypsin & - & $+(3)$ & $(+) \dagger$ \\
$N$-Acetyl- $\beta$-glucosaminidase & & & \\
(constitutive) & - & $+(26)$ & - \\
Utilization of: & - & $+(34)$ & - \\
Glycogen & - & $+(34)$ & - \\
Gentiobiose & $-\S$ & $+(34)$ & - \\
Cellobiose & - & $+(34)$ & - \\
Sucrose & - & $+(34)$ & - \\
D-Gluconate & & & \\
Citrate & & & \\
\hline
\end{tabular}

* Numbers in parentheses are the number of positive strains.

† Strains NCTC 10735 and NCTC 10736 showed a weak reaction, whereas the Baltic isolates OS155 and OS195 were negative.

$\ddagger$ Weak reaction.

$\S$ LMG 2369 was positive.

In summary, phylogenetic, genotypic and phenotypic data clearly demonstrated that all genomic groups within $S$. putrefaciens are distant enough to be classified as different species according to the definition of Wayne et al. (42). We propose the name Shewanella baltica sp. nov. for genomic group II because the majority of known strains have been isolated from water samples of the Baltic Sea. Genomic group III should probably also be classified as a new species, but further taxonomic analysis should be carried out including more strains which are available in various culture collections $(12,27,28)$.

\section{Description of Shewanella baltica sp. nov.}

Shewanella baltica (Ziemke and Rosselló-Mora) (bal.ti.ca. L. fem. adj. baltica of the Baltic Sea, where the majority of strains were isolated).

Gram-negative, short straight rod, motile by polar flagellation, facultative anaerobe but non-fermentative. Catalase- and oxidase-positive. Most of the colonies of fresh isolates show a black FeS precipitate on TSI agar medium. Under anaerobic conditions, oxidation of organic matter can be coupled to the reduction of $\mathrm{NO}_{3}^{-}, \mathrm{Fe}^{3+}$ and sulfur compounds. Members of the species can easily be differentiated phenotypically from the related species by their ability to grow at $4{ }^{\circ} \mathrm{C}$, but not at $37^{\circ} \mathrm{C}$, constitutive production of $N$-acetyl- $\beta$-glucosaminidase, lack of chymotrypsin production and the ability to use glycogen, gentiobiose, cellobiose, sucrose, D-gluconate and citrate as sole sources of carbon and energy (Table 3). The $\mathrm{G}+\mathrm{C}$ content of the species is $45 \cdot 7-46 \cdot 8 \mathrm{~mol} \%$. The type strain of the species is NCTC 10735 (= DSM 9439, CECT 323, IAM 1477, LMG 2250). It was isolated from oil brine (16) and has a $\mathrm{G}+\mathrm{C}$ content of $46 \cdot 1 \mathrm{~mol} \%$.

\section{ACKNOWLEDGEMENTS}

We gratefully acknowledge Ingrid Brettar for the provision of a large number of Baltic isolates. We thank Annette Krüger and Carsten Strömpl for excellent technical assistance with the 16S rRNA gene sequencing and Rudolf Amann, Jakob Pernthaler and Markus G. Weinbauer for critical comments on the manuscript. Wolfgang Ludwig is acknowledged for providing the ARB program and a large database of $16 \mathrm{~S}$ rRNA sequences. This study was supported by funds from the Bundesministerium für Bildung, Wissenschaft, Forschung und Technologie (grant BEO0319433B), the EC project 'High Resolution Automated Microbial Identification' (EC-HRAMI) and the project AMB94-0760 from CICYT (Spain).

\section{REFERENCES}

1. Brenner, D. J., Fanning, G. R., Rake, A. V. \& Johnson, K. E. (1969). Batch procedure for thermal elution of DNA from hydroxyapatite. Anal Biochem 28, 447-459.

2. Brettar, I. \& Höfle, M. G. (1993). Nitrous oxide producing 
heterotrophic bacteria from the water column of the central Baltic, abundance and molecular identification. Mar Ecol Prog Ser 94, 253-265.

3. Brosius, J., Dull, T. L., Sleeter, D. D. \& Noller, H. F. (1981). Gene organization and primary structure of a ribosomal RNA operon from Escherichia coli. J Mol Biol 148, 107-127.

4. Caccavo, J. R., Blakemore, R. P. \& Lovely, D. R. (1992). A hydrogen-oxidizing, $\mathrm{Fe}$ (III)-reducing microorganism from the Great Bay Estuary, New Hampshire. Appl Environ Microbiol 58, 3211-3216.

5. Cerdà-Cuéllar, M., Rosselló-Mora, R., Lalucat, J., Jofre, J. \& Blanch, A. (1997). Vibrio scophthalmi sp. nov., a new species from turbot (Scophthalmus maximus). Int J Syst Bacteriol 47, 58-61.

6. Debois, J., Degreef, H., Vandepitte, J. \& Spaepen, J. (1975). Pseudomonas putrefaciens as a cause of infection in humans. $J$ Clin Pathol 28, 993-996.

7. Derby, H. A. \& Hammer, B. W. (1931). Bacteriology of butter. IV. Bacteriological studies of surface taint butter. Iowa Agric Exp Stn Res Bull 145, 387-416.

8. DiChristina, T. J. \& DeLong, E. F. (1993). Design and application of rRNA-targeted oligonucleotide probes for the dissimilatory iron- and manganese-reducing bacterium Shewanella putrefaciens. Appl Environ Microbiol 59, 4152-4160.

9. Domínguez, H., Fonnesbech Vogel, B., Gram, L., Hoffmann, S. \& Schæbel, S. (1996). Shewanella alga bacteremia in two patients with lower leg ulcers. Clin Infect Dis 22, 1036-1039.

10. Edwards, U., Rogall, T., Blöcker, H., Emde, M. \& Böttger, E. C. (1989). Isolation and direct nucleotide determination of entire genes. Characterization of a gene coding for $16 \mathrm{~S}$ ribosomal RNA. Nucleic Acids Res 17, 7843-7853.

11. Felsenstein, J. (1982). Numerical methods for inferring phylogenetic trees. $Q$ Rev Biol 57, 379-404.

12. Fonnesbech Vogel, B., Jørgensen, K., Christensen, H., Olsen, J. E. \& Gram, L. (1997). Differentiation of Shewanella putrefaciens and Shewanella alga on the basis of whole-cell protein profiles, ribotyping, phenotypic characterization, and 16S rRNA gene sequence analysis. Appl Environ Microbiol 63, 2189-2199.

13. Höfle, M. G. \& Brettar, I. (1996). Genotyping of heterotrophic bacteria from the central Baltic Sea using low-molecularweight RNA profiles. Appl Environ Microbiol 62, 1382-1390.

14. Holmes, B., Lapage, S. B. \& Malnick, H. (1975). Strains of Pseudomonas putrefaciens from clinical material. $J$ Clin Pathol 28, 149-155.

15. Hutson, R. A., Thompson, D. E. \& Collins, M. D. (1993). Genetic interrelationships of saccharolytic Clostridium botulinum types B, E and F and related clostridia as revealed by small-subunit rRNA gene sequences. FEMS Microbiol Lett 108, 103-110.

16. lizuka, H. \& Komagata, K. (1964). Microbiological studies on petroleum and natural gas. II. Determination of pseudomonads isolated from oilbrines and related materials. $J$ Gen Appl Microbiol 10, 223-231.

17. Jørgensen, B. R. \& Huss, H. H. (1989). Growth and activity of Shewanella putrefaciens isolated from spoiling fish. Int $J$ Food Microbiol 9, 51-62.

18. Karlson, U., Dwyer, D. F., Hooper, S. W., Moore, E. R. B., Timmis, K. N. \& Eltis, L. D. (1993). Two independently regulated cytochromes P-450 in Rhodococcus rhodochrous strain that degrades 2-ethoxyphenol and 4-methoxybenzoate. $J$ Bacteriol 175, 1467-1474.

19. Kim, J. H., Cooper, R. A., Welty-Wolff, K. E., Harrell, L. J., Zwadyk, P. \& Klotman, M. E. (1989). Pseudomonas putrefaciens bacteremia. Rev Infect Dis 11, 97-104.

20. Lane, D. J. (1991). 16S/23S rRNA sequencing. In Nucleic Acid Techniques in Bacterial Systematics, pp. 115-175. Edited by E. Stackebrandt \& M. Goodfellow. Chichester: John Wiley.

21. Lee, J. V., Gibson, D. M. \& Shewan, J. M. (1977). A numerical taxonomy study of some Pseudomonas-like marine bacteria. J Gen Microbiol 98, 439-451.

22. Lind, E. \& Ursing, J. (1986). Clinical strains of Enterobacter agglomerans (synonyms, Erwinia herbicola, Erwinia milletiae) identified by DNA-DNA-hybridization. Acta Pathol Microbiol Immunol Scand Sect B 94, 205-213.

23. MacDonell, M. T. \& Colwell, R. R. (1985). Phylogeny of the Vibrionaceae and recommendation for two new genera, Listonella and Shewanella. Syst Appl Microbiol 6, 171-182.

24. Maidak, B. L., Olsen, G., Larsen, N., Overbeek, R., MacCaughey, M. J. \& Woese, C. R. (1996). The Ribosomal Database Project. Nucleic Acids Res 24, 82-85.

25. Marmur, J. (1961). A procedure for the isolation of DNA from microorganisms. J Mol Biol 3, 208-218.

26. Nealson, K. H. \& Saffarini, D. (1994). Iron and manganese in anaerobic respiration, environmental significance, physiology, and regulation. Annu Rev Microbiol 48, 311-343.

27. Nozue, H., Hayashi, T., Hashimoto, Y., Ezaki, T., Hamasaki, K., Ohwada, K. \& Terawaki, Y. (1992). Isolation and characterization of Shewanella alga from human clinical specimens and emendation of the description of $S$. alga Simidu et al., 1990, 335. Int J Syst Bacteriol 42, 628-634.

28. Owen, R. J., Legros, R. M. \& Lapage, S. P. (1978). Base composition, size and sequence similarities of genome deoxyribonucleic acids from clinical isolates of Pseudomonas putrefaciens. J Gen Microbiol 104, 127-138.

29. Perry, K. A., Kostka, J. E., Luther, G. W., III \& Nealson, K. H. (1993). Mediation of sulfur speciation by a Black Sea facultative anaerobe. Science 259, 801-803.

30. Rossello-Mora, R. A., Cavacco, F., Jr, Osterlehner, K., Springer, N., Spring, S., Schüler, D., Ludwig, W., Amann, R., Vanncanneyt, M. \& Schleifer, K. H. (1994). Isolation and taxonomic characterization of a halotolerant facultatively iron-reducing bacterium. Syst Appl Microbiol 17, 569-573.

31. Rosselló-Mora, R. A., Ludwig, W., Kämpfer, P., Amann, R. \& Schleifer, K. H. (1995). Ferrimonas balearica gen. nov., spec. nov, a new marine facultative $\mathrm{Fe}$ (III)-reducing bacterium. Syst Appl Microbiol 18, 196-202.

32. Rüger, H.-J. \& Krambeck, H.-J. (1994). Evaluation of the BIOLOG substrate metabolism system for classification of marine bacteria. Syst Appl Microbiol 17, 281-288.

33. Semple, K. M. \& Westlake, D. W. S. (1987). Characterization of iron-reducing Alteromonas putrefaciens strains from oil field fluids. Can J Microbiol 33, 366-371.

34. Shewan, J. M. (1977). The bacteriology of fresh and spoiling fish and the biochemical changes induced by bacterial action. In Proceedings of the Conference on Handling, Processing and Marketing of Tropical Fish, pp. 51-66. London: Tropical Products Institute.

35. Shewan, J. M., Hobbs, G. \& Hodgkiss, W. (1960). A determinative scheme for the identification of certain genera 
of Gram-negative bacteria with special reference to Pseudomonadaceae. J Appl Bacteriol 23, 379-390.

36. Simidu, U., Kita-Tsukamoto, K., Yasumoto, T. \& Yotsu, M. (1990). Taxonomy of four marine bacterial strains that produce tetrodotoxin. Int J Syst Bacteriol 40, 331-336.

37. Stenström, I. M. \& Molin, G. (1990). Classification of the spoilage flora of fish, with special reference to Shewanella putrefaciens. J Appl Bacteriol 68, 601-618.

38. Strunk, O., Gross, O., Reichel, B. \& 11 other authors. ARB, a software environment for sequence data (submitted for publication).

39. Tijssen, P. (1985). Practice and theory of enzyme immunoassays. In Laboratory Techniques in Biochemistry and Molecular Biology, vol. 15. Edited by R. H. Burdon \& P. H. van Knippenberg. Amsterdam: Elsevier.

40. Vaneechoutte, M., Rossau, R., de Vos, P., Gillis, M., Janssens, D., Paepe, N., de Rouck, A., Fiers, T., Claeys, G. \& Kersters, K.
(1992). Rapid identification of bacteria of the Comamonadaceae with amplified ribosomal DNA-restriction analysis (ARDRA). FEMS Microbiol Lett 93, 227-234.

41. Van Landschoot, A. \& de Ley, J. (1983). Intra- and intergeneric similarities of the rRNA cistrons of Alteromonas, Marinomonas (gen. nov.) and some other Gram-negative bacteria. J Gen Microbiol 129, 3057-3074.

42. Wayne, L. G., Brenner, D. J., Colwell, R. R. \& 9 other authors (1987). International Committee on Systematic Bacteriology. Report of the Ad Hoc Committee on reconciliation of approaches to bacterial systematics. Int J Syst Bacteriol 37, 463-464.

43. Ziemke, F., Brettar, I. \& Höfle, M. G. (1997). Stability and diversity of the genetic structure of a Shewanella putrefaciens population in the water column of the central Baltic. Aquat Microb Ecol 13, 63-74.

44. Ziemke, F. \& Hofle, M. G. Unpublished data. 